\title{
PENDIDIKAN AGAMA PADA ANAK MUCIKARI DI LOKALISASI GAMBILANGU MANGKANG SEMARANG
}

\author{
A. Saiful Aziz \\ Dosen Fakultas Agama Islam Universitas Wahid Hasyim Semarang
}

\begin{abstract}
Education is recognized as a force that can help the Society achieve the splendor and progress of civilization. Religious education directly touches the very essence of the essence of the students, especially in terms of values, attitudes, and practice of religion. Education will provide positive values, attitudes, and demands of behavior and religious examples. The more religious experience, and the more religious elements, the attitudes and actions, behavior and way of dealing with life will be in accordance with the teachings of religion.

This study aims to find and describe the profile of pimp children, the forms of religious education obtained by pimp children and the experience of pimping children's education. Based on the above description, the authors emphasize the following issues: (1) Where do pimp kids get religious education? (2) What aspects of religion do pediatric children gain in religious education in pimp children in the localization of gambilangu Mangkang Semarang?

This study uses a qualitative approach, a study that seeks to reveal the state of a natural nature as a whole. Qualitative research is used to understand the community, problems and symptoms by collecting as much as possible facts that can be observed. The method used is descriptive method that aims to describe the problem systematically.

Islamic education in pimp children in lokalisasi gambilangu mangkang semarang has run although not ideal yet. Pimped children receive Islamic Education in schools (Primary and Kindergarten), Qur'anic Education Park and Village Neighbor's mosque and some are in Musolla (the only localized musolla). From these educational institutions pimp children get knowledge about aqidah / faith, worship and morals.
\end{abstract}

Keywords: Education, Pimps, Child, Localization.

\section{PENDAHULUAN}

Pendidikan mempunyai arti terpenting dalam kehidupan manusia, pendidikan diakui sebagai kekuatan yang dapat membantu masyarakat mencapai kemegahan dan kemajuan peradaban. Tidak ada satu prestasi pun tanpa adanya peranan pendidikan. Dalam kehidupan sehari-hari, istilah pendidikan agama sudah cukup dikenal oleh masyarakat Indonesia. Sehingga baik secara historis maupun filosofis, pendidikan agama telah mewarnai dan menjadi landasan spiritual, moral dan etika dalam proses pembentukan jati diri masyarakat. Pendidikan ditujukan untuk meningkatkan kualitas sumber 
daya manusia. Dalam Undang-undang RI Nomor 20 Tahun 2003 tentang Sistem Pendidikan Nasional yang berbunyi bahwa:

"Pendidikan nasional berfungsi mengembangkan kemampuan dan membentuk watak serta peradaban bangsa yang bermartabat dalam rangka mencerdas-kan kehidupan bangsa, bertujuan untuk berkembangnya potensi peserta didik agar menjadi manusia yang beriman dan bertakwa kepada Tuhan Yang Maha Esa, berakhlak mulia, sehat, berilmu, cakap, kreatif, mandiri dan menjadi warga negara yang demokratis serta bertanggung jawab" (UU Sisdiknas, 2003: 3).

Pendidikan agama secara langsung menyentuh esensi yang sangat mendasar pada diri peserta didik, terutama dari segi nilai, sikap, dan pengamalan agamanya. Dapat dipastikan bahwa pendidikan akan memberikan nilai, sikap, dan tuntutan perilaku serta contoh keagamaan yang positif. Semakin banyak pengalaman yang bersifat agama, dan semakin banyak unsur agama, maka sikap dan tindakan, kelakuan dan caranya menghadapi hidup akan sesuai dengan ajaran agama. ${ }^{1}$ Peran orang tua dalam mendidik anak sangat menentukan dalam pembentukan karakter dan perkembangan kepribadian pada anak. Disadari maupun tidak disadari, remaja dapat terkena imbas dari globalisasi yang negatif, terutama bila dalam tumbuh kembangnya tidak diimbangi dengan perhatian dan bimbingan dari orang tua.

Melihat fenomena yang ada di lapangan terhadap kondisi dan keadaan kehidupan anak yang ada, sebagai contoh adalah anak mucikari yang hidup di kompleks lokalisasi Gambilangu Mangkang Semarang. Pada penelitian ini ditemukakn problem pada anak mucikari, meskipun anak mucikari sudah memperoleh pendidikan agama Islam di bangku sekolah (pendidikan formal), akan tetapi anak mucikari belum bisa menerapakan nilai- nilai agama yang sudah didapatkan dari pendidikan formal. Maka dalam pelaksanaan pendidikan agama terhadap anak mucikari ini harus dilaksanakan secara komprehensif, terprogram, berkesinambungan serta perlu adanya suatu

\footnotetext{
${ }^{1}$ Daradjat, Zakiah, 2005, Ilmu Jiwa Agama, Jakarta: Bulan Bintang, hlm 66
} 
pendekatan persuasif dengan kondisi mereka di lingkungan yang rentan terhadap tindakan-tindakan yang kurang normatif.

Dengan pendidikan agama, khususnya pendidikan Islam, anak mucikari diharapkan dapat menuju hidup yang sehat, memiliki pengetahuan agama yang berguna untuk sekarang dan masa depan. disamping itu diharapkan tetap mempunyai mekanisme pertahanan diri untuk menghindari pengaruh negatif kehidupan jalanan dan memiliki pemikiran positif tentang hidupnya. Dengan tujuan ini, kegiatan pendidikan lebih mengarah pada penanaman nilai, penanaman wawasan serta pembentukan sikap dan perilaku yang baik. Secara khusus penelitian ini bertujuan untuk mengetahui dan mendeskripsikan tentang profil anak mucikari, bentuk-bentuk pendidikan agama yang diperoleh anak mucikari dan pengalaman pendidikan anak mucikari.

\section{LANDASAN TEORI}

\section{A. Pengertian Pendidikan Agama Islam}

Kamus Bahasa Indonesia, pendidikan diartikan sebagai proses pengubahan cara berpikir atau tingkah laku dengan cara pengajaran, penyuluhan dan latihan proses mendidik. Ahmad Tafsir mengemukakan pendidikan Islam adalah bimbingan terhadap seseorang agar ia menjadi muslim semaksimal mungkin. Naquib al-Attas mendefinisikan pendidikan dalam The Concept of Islamic Education sebagai berikut :

"Education is a process of instilling something into human beings" (pendidikan adalah suatu proses menanamkan sesuatu pada seseorang ). ${ }^{2}$

Muhammad Athiyah Al-Abrasy di dalam kitabnya Ruh At-Tarbiyah Wa At-Ta'lim disebutkan bahwa :

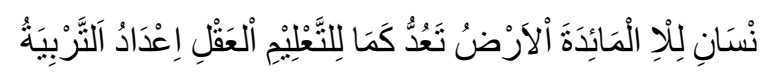

“ Pendidikan adalah mempersiapkan akal untuk belajar sebagaimana bumi menyiapkan makanan untuk manusia". 3

\footnotetext{
2 al-Attas Naquib, Syed Muhammad, 1980, The Concept of Islamic Education Makkatul Mucaxlxlamah in March I 977, hlm 3

${ }^{3}$ Tafsir, Ahmad, 2012, Ilmu Pendidikan dalam Perspektif Islam, Bandung: PT Remaja Rosda karya, hlm 8
} 
Undang-Undang Nomor 20 tahun 2003 tentang Sistem Pendidikan Nasional menyatakan, yang dimaksud dengan pendidikan adalah usaha sadar dan terencana untuk mewujudkan suasana belajar dan proses pembelajaran agar anak didik secara aktif mengembangkan potensi dirinya untuk memiliki kekuatan spiritual keagamaan, pengendalian diri, kepribadian, inteligensi, akhlak mulia, serta ketrampilan yang diperlukan dirinya, masyarakat, bangsa dan negara.

Adapun mengenai arti kata "agama" bahwa dalam Oxford Advanced Leaner's Dictionary of Current English, dinyatakan, bahwa:

"Religion: believe in the existenced of God or gods, Who has/have created the universe and given man a spiritual nature which continuous to exist after the dead of the body" (1974: 712). (agama adalah suatu kepercayaan terhadap adanya Tuhan Yang Esa, atau Tuhan-Tuhan, yang telah menciptakan alam semesta, dan memberikan roh kepada manusia yang akan tetap ada setelah matinya badan).

James Luther Adams juga menyatakan bahwa "Religion is directedness of the spirit toward the unconditioned meaning".

Dalam istilah bahasa Arab dan AlQur'an, kata agama dapat searti dengan Addin. Jika kata Addin dirangkaikan dengan Allah atau Islam, maka menjadi dinul Allah atau dinul Islam, yang berarti agama yang datang dari Allah atau agama Islam.

Prof Mahmud Syaltout mengatakan:

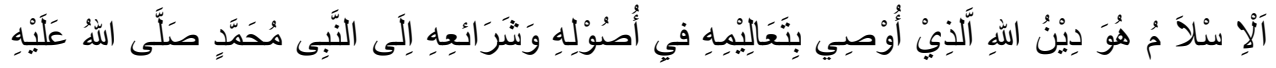

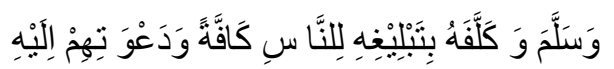

( Agama Islam adalah agama Allah yang disampaikan kepada Nabi Muhammad SAW untuk di pelajari pokok-pokok syariatnya dan dituntut untuk menyampaikannya serta mengajar kepada semua manusia). ${ }^{4}$

Sedangkan Islam merupakan nama dari suatu agama yang dibawa oleh nabi Muhammad saw. AL Tibawi berpendapat “ Islam means

\section{Qolam}

${ }^{4}$ Mahmud Syaltout, Lil Alamil Akbar, 1966, Al Islam Aqidah Wa Syari'ah, Mesir: Darul 
submission, the subbmission of man's will to God's commandments" (Islam berarti bentuk pengabdian kehendak manusia kepada perintahperintah Allah). Begitupun juga Abul A'la (1960) mengatakan “Islam is an Arabic word and connotes submission, surender and obedience. As a religion, Islam stands for complete submission and obedience to Allah" (Islam merupakan bahasa Arab yang berarti penyerahan, berserah dan ketaatan . Sebagai agama, Islam merupakan agama yang sempurna dan sebagai bentuk ketaatan kepada Allah). ${ }^{5}$ Kata Islam pada pendidikan agama Islam menunjukkan warna pendidikan tertentu, pendidikan yang berwarna Islam yang secara normatif berdasarkan al-Quran dan as-Sunnah.

Dari beberapa definisi yang dikemukakan oleh tokoh pendidikan di atas, maka pendidikan adalah suatu bimbingan secara sistematis oleh seorang pendidik menuju pembentukan kepribadian yang mulia, yaitu terbentuknya manusia beriman dan bertaqwa serta memiliki kemampuan dalam berhubungan dengan Tuhan, sesama manusia dan alam sekitarnya secara positif dan dinamis.

Pengertian pendidikan agama Islam secara formal dalam kurikulum berbasis kompetensi dikatakan:

" Pendidikan agama Islam adalah upaya sadar dan terencana dalam menyiapkan peserta didik untuk mengenal, memahami, menghayati hingga mengimani, bertakwa, dan berakhlak mulia dalam mengamalkan ajaran agama Islam dari sumber utamanya kitab suci Al-Qur'an dan hadis, melalui kegiatan bimbingan, pengajaran, latihan, serta penggunaan pengalaman. Dibarengi tuntutan untuk menghormati penganut agama lain dalam masyarakat hingga terwujudnya kesatuan dan persatuan bangsa “6

Ribut Purwojuono menyatakan "Islamic education, which can be interpreted simply as an education based on the values of Islamic teachings as stated in Al-Qur'an and the Sunnah of the Prophet (peace and blessings of Allah be upon him)" . Bahwasanya Pendidikan Agama Islam,

\footnotetext{
${ }^{5}$ A.L-Tibawi , 1972, Islamic Education in Traditions and Modernization into theArab National Systems, London: Luzac Company Ltd, hlm 1

${ }^{6}$ Depdiknas, 2012, Kamus Besar Bahasa Indonesia, Jakarta: Balai Pustaka, hlm 6
} 
secara sederhana dapat diartikan sebagai pendidikan berbasis pada nilainilai ajaran Islam seperti yang dinyatakan di Al -Qur'an dan Sunnah Nabi. ${ }^{7}$

Jadi dari uraian tersebut dapat diambil suatu pemahaman bahwa Pendidikan Agama Islam adalah suatu proses mempersiapkan dan menumbuhkan anak didik atau individu manusia yang prosesnya berlangsung secara terus-menerus sejak ia lahir sampai meninggal dunia, meliputi aspek jasmani, akal, dan ruhani sebagai suatu kesatuan dan memberikan nilai-nilai berdasarkan hukum-hukum Islam untuk mengarahkan potensi dan kemampuan dasar sehingga terjadilah perubahan di dalam kehidupannya menuju terbentuknya kepribadian utama demi kebahagiaan di dunia dan akhirat.

\section{B. Tujuan Pendidikan Agama Islam Pada Anak Mucikari}

Dalam proses pendidikan, tujuan pendidikan agama Islam secara umum tidaklah lepas dari tujuan hidup manusia menurut syariat Islam, yaitu mengabdi kepada Allah untuk mencapai kebahagian hidup di dunia dan di akhirat. Sebagaimana yang tertulis dalam QS. Adz-Dzariat : 56 :

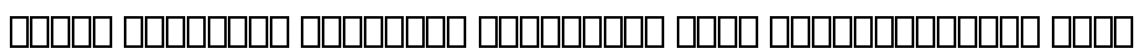

Artinya : "Dan tidak Aku (Allah) ciptakan jin dan manusia kecuali hanya untuk mengabdi kepadaku “(Q.S. Adz Zariat : 56).

Tujuan pendidikan yang paling sederhana adalah "memanusiakan manusia" atau membantu manusia menjadi manusia". Manusia dalam proses pendidikan adalah inti utama.

Pasal 3 Undang-Undang Republik Indonesia Nomor 20 tahun 2003 tentang Sistem Pendidikan Nasional ditegaskan bahwa pendidikan nasional berfungsi mengembangkan kemampuan dan membentuk watak serta peradaban bangsa yang bermartabat dalam rangka mencerdaskan kehidupan bangsa, bertujuan untuk berkembangnya potensi peserta didik agar menjadi manusia yang beriman dan bertakwa kepada Tuhan Yang

7 Purwojuono, Ribut, Hamka's Education Thinking: Gender Equality in Islamic Education, Journal of Social Sciences and Humanities, 2015, 105-113, hlm 106 
Maha Esa, berakhlak mulia, sehat, berilmu, cakap, kreatif, mandiri, dan menjadi warga negara yang demokratis serta bertanggungjawab ${ }^{8}$

Tujuan pokok dari pendidikan agamaIslam menurut Athiyah alAbrasyi ialah mendidik budi pekerti dan pembentukan jiwa. Semua mata pelajaran haruslah mengandung pelajaran-pelajaran akhlak, setiap pendidik haruslah memikirkan akhlak dan memikirkan akhlak keagamaan sebelum yang lain-lainnya karena akhlak keagamaan adalah akhlak yang tertinggi, sedangkan, akhlak yang mulia itu adalah tiang dari pendidikan Islam.

Sobhi Rayan, mengatakan "Islamic Education aims to make Balance between three levels: sense, mind and ethics, and promoting them by various Educational methods". Pendidikan agama Islam bertujuan untuk menyeimbangkan tiga hal antara lain: akal, pikiran dan etika , dengan berbagai metode Pendidikan. ${ }^{9}$

Pendidikan agama Islam pada anak mucikari bertujuan adalah mendidik anak, mengarahkan untuk menjadi anak yang shalih dan shalihah, bisa dapat baca tulis al-Qur'an (BTQ) dengan baik dan tartil serta membentuk akhlakul karimah supaya kelak berguna bagi agama, nusa dan bangsa serta menumbuhkembangkan rasa keberagamaan dalam lingkungan lokalisasi. Pada umumnya sebagai bentuk da'wah Islamiyah selain itu merubah image masyarakat bahwa kehidupan di lingkungan lokalisasi tidak identik dengan dunia pelacuran saja melainkan terdapat kehidupan keberagamaan di kalangan masyarakat setempat.

Berdasarkan uraian di atas, maka dapat diambil kesimpulan bahwa tujuan pendidikan Islam adalah membina dan mengarahkan potensi akal, jiwa dan jasmaninya, sehingga ia memiliki ilmu, akhlak dan keterampilan yang semua ini dapat digunakan guna mendukung tugas pengabdian dan kekhalifahannya di muka bumi.

\footnotetext{
8 (Undang-Undang Republik Indonesia, nomor 20 tahun 2003, hlm 3

9 Rayyan, Shobhi, 2012, Islamic Philosophy of Education, Intemational Journal of Humanities and Social Science, , 150-156, hlm 155
} 


\section{Kewajiban Orang Tua Terhadap Anaknya}

Bagi ayah dan ibu, anak merupakan belahan jiwa dan harapan hi-dupnya, penyambung dan penerus keturunan dan mengharumkanorang tuanya (jika shaleh). Jika kedua pihak (suami istri) shaleh, selalurukun dan damai dalam keluargannya, saling mencintai dan saling to-long-menolong, maka anak-anak mereka akan menjadi anak yang salehdan terjaga dari tekanan jiwa, terlepas dari penyimpangan dan kenakalan remaja serta terbebas dari sifat-sifat buruk lainnya. ${ }^{10}$

Selanjutnya Djatnika Rahmat menyatakan bahwa teori-teori kon- vensioal yang dikemukakan oleh John Rocke melukiskan jiwa anak se-perti kaset yang kosong. Dia akan merekam apa yang dilihat, apa saja yang di dengar. Kalau yang didengar itu baik, nanti kalau diputar kembali akan baik. Oleh karena itu ayah dan ibu yang muslim perlu mengadzani anaknyayangbarulahir. ${ }^{11}$

Dalam Islam, Orang tua mempunyai kewajiban terhadap anak seperti: mengazani anak yang baru lahir, memberi nama yang baik danbagus, mengaqiqah, mencukur rambut, memberi nafkah, dan mengkhitankan. Hal tersebut di atas merupakan sesuatu yang harus dilakukankeluarga muslim dalam mengapresiasikan nilai-nilai agama pada ke-hidupan anak yang harus dipenuhi. Orang tua pada awalnya di dalammembantu anak berupaya agar anak tampil dengan predikat anak yangsaleh dan shalehah.

\section{Prostitusi, mucikari dan lokalisasi}

a) Definisi Prostitusi

Prostitusi, adalah melakukan hubungan seksual dengan berganti- ganti pasangan yang bukan istri atau suaminya, yang dilakukan d itempat - tempat tertentu (lokalisasi, hotel, tempat rekreasi dan lain- lain), yang pada umumnya mereka mendapatkan uang setelah melakukan hubungan badan.Para

${ }^{10}$ Zakiah Darojat, Peranan Agama Dalam Kesehatan Mental (Jakarta : GunungAgung, 1973), hlm.

${ }^{11}$ Djatnika Rahmat, Sistem Etika Islam (Surabaya: Pustaka Islam 1985) hlm 78 
penjual diri tersebut sering disebut WTS (Wanita Tuna Susila). ${ }^{12}$

Mereka adalah para wanita yang tidak mempunyai susila (adab, akhlak, kesopanan). Sedang para pembelinya disebut hidung belang, yaitu para pembeli sex yang menghamburhamburkan uangnya demi terpuaskannya nafsu birahi. Lokalisasinya disebut kompleks pelacuran atau ajang berkumpul dalam melakukan pesta sexnya. Adapun orang yang menampung para pelacur dan hidung belang dalam melakukan transaksi sexnya disebut mucikari atau germo. Orang inilah yang amat mendukung terlaksananya pesta maksiat itu. Ia mendapat imbalan dari para pelacur dari penghasil annya, sekian persen.Profesi semacam itulah yang kini banyak diminati kaum remaja masa kini, terutama yang berdomisili dikota- kota besar, seperti kota propinsi dan kota metropolitan. Sungguh sangat memprihatinkan bila melihat kondisi remaja zaman sekarang. Masih berusia belasan tahun, tetapi seringkali dibawa om- om hidung belang, dengan mobil mewah ke sebuah cottage, villa maupun bungalow. Disitu mereka asyik masuk melakukan kemaksiatan dengan imbalan tertentu. Remaja ini sering disebut dengan istilah "perex atau perempuan eksperimen". Apapun namanya ia tetap seorang pelacur, meskipun ia hanya menjual dirinya kepada hidung belang yang berkantong tebal, yang hanya mau mencari daun muda untuk teman kencan seksnya. Pelacuran sudah ada sejak zaman para nabi. Namun pelacur- pelacur dahulu berprofesi secara terselubung, sebab mungkin saja para pelakunya masih sedikit mempunyai malu dengan sesama manusia, bila mereka mendapatkan sebutan pelacur, meskipun profesi yang sebenarnya

${ }^{12}$ Heriana Eka Dewi, Memahami Perkembangan Fisik Remaja, (Yogyakarta : Gosyen Publishing, 2012), hal. 81 
ialah pelacur. Kebanyakan profesi ini pada zaman dahulu adalah karena keterpaksaan, disebabkan ekonomi yang morat- marit. ${ }^{13}$

Sekarang ini profesi pelacur benar-benar sudah menjadi pekerjaan atau suatu profesi, bukan karena keterpaksaan. Mereka menyediakan tubuhnya untuk dijamah dan dijajah, asal dengan imbalan yang tertentu. Pelacuran zaman sekarang dilakukan dengan terbuka, terang- terangan, seakan mereka justru bangga berprofesi menjadi pelacur. Pekerjaan ini seakan bukan aib lagi di masyarakat, bahkan ada sebagian masyarakat yang menyediakan tempat untuk para pelacur untuk bermaksiat kepada Allah SWT. Menurut mereka pekerjaan seperti ini enak, kerja ringan tapi bayaran tinggi. Kerja 10 menit paling sedikit mendapat imbalan 25.000 rupiah. Itulah mengapa, mereka menggeluti dunia hitam ini..

Pada peristiwa pelacuran itu ada dorongan- dorongan seks yang tidak terintegrasi dengan kepribadian. Artinya, implus - implus seks itu tidak terkendali oleh hati nurani. Selanjutnya, dipakailah teknik- teknik seksual yang amat kasar dan provokatif dalam sangga ma, dan sangat impersonal karena berlangsung efeksi tanpa perasaan, emosi dan kasih sayang, sehingga dilakukan dengan cepat, dan tanpa orgasme pada pihak wanita/pelacurnya. Fenomena yang terjadi bukan lagi menjadi rahasia karena apabila ditelusuri lebih mendalam sungguh malang nasib anak muda semacam ini. Pagi ia belajar disekolah, sementara malamnya ia keluyuran ke diskotik, ke mall- mall yang memang biasa untuk mangkal. Khusus untuk perek remaja, sekarang ini ada istilah “Ayam Abu - abu”. Sebutan ini mungkin muncul karena mereka berkeliaran dengan memakai seragam sekolah mereka, yakni abu- abu putih untuk seragam menengah atas dan biru putih untuk seragam sekolah lanjutan pertama

${ }^{13}$ Fuad Kauma, Sensasi Remaja di Masa Puber, (Jakarta : Kalam Mulia, 1999), hal. 80 
b) Definisi Lokalisasi

Lokalisasi memliki pengertian yang terisolasi atau terpisah dari kompleks penduduk lainnya. Kompleks ini dikenal sebagai daerah lampu merah, atau petak-petak daerah tertutup. Lokalisasi pada umumnya terdiri atas rumah-rumah kecil yang berlampu merah, yang dikelola mucikari atau germo. Ditempat tersebut disediakan segala perlengkapan, tempat tidur, kursi tamu, pakaian, alat berhias, dan juga tersedia berbagai macam gadis dengan tipe karakter dan suku bangsa yang berbeda. ${ }^{14}$

Di lokalisasi, diterapkan kedisiplinan ketat misalnya tidak boleh mencuri uang pelanggan, dilarang berebut langganan orang lain, tidak boleh mengadakan janji diluar, dilarang memonopoli pelanggan. Wanita-wanita pelacur itu harus membayar pajak rumah dan pajak obat-obatan, sekaligus uang keamanan agar mereka terlindung dan terjamin identitasnya.

c) Tujuan Lokalisasi

Menurut Kartono tentang tujuan dari loakalisasi adalah sebagai berikut:

a) Untuk menjauhkan masyarakat umum, terutama anak-anak puber dan remaja dari pengaruh-pengaruh immoril praktik pelacuran.

b) Memudahkan pengawasan para wanita tunasusila, terutama mengenai kesehatan dan keamanannya.

c) Mencegah pemerasan yang keterlaluan terhadap para pelacur, yang pada umumnya selalu menjadi pihak yang paling lemah

d) Memudahkan bimbingan mental bagi para pelacur, dalam usaha rehabilitasi dan resosialisasi. Kadang

${ }^{14}$ Kartono, K. 2011. Patologi Sosial. Jakarta : PT. Radja Grafindo Persada, hlm 43 
diberikan pendidikan dan latihan-latihan kerja, sebagai persiapan untuk kembali ke dalam masyarakat biasa.

e) Kalau mungkin diusahakan pasangan hidup bagi para tunasusila yang benarbenar bertanggung jawab. ${ }^{15}$

d) Mucikari

Mucikari atau dalam kamus besar bahasa Indonesia merujuk kepada kata Muncikari adalah induk semang bagi perempuan lacur atau germo. Namun pemahaman masyarakat secara luas adalah orang yang berperan sebagai pengasuh, perantara, dan "pemilik" pekerja seks komersial (PSK). Dalam kebanyakan bisnis seks, khususnya yang bersifat massal, pekerja seks biasanya tidak berhubungan langsung dengan pengguna jasa. Mucikari berperan sebagai penghubung kedua pihak ini dan akan mendapat komisi dari penerimaan PSK yang persentasenya dibagi berdasarkan perjanjian. Mucikari biasanya amat dominan dalam mengatur hubungan ini, karena banyak PSK yang "berhutang budi" kepadanya. Banyak PSK yang diangkat dari kemiskinan oleh mucikari, walaupun dapat terjadi eksploitasi oleh mucikari kepada "anak asuh"nya. Seperti ini pula mucikari dalam dunia prostitusi baik yang online atau di tempat yang sudah dilegalkan oleh pemerintah, mereka hanya sebagai penghubung antara pekerja seks komersial dengan mereka lelaki hidung belang. ${ }^{16}$

\section{METODE PENELITIAN}

\section{A. Pendekatan Penelitian}

Penelitian ini menggunakan pendekatan kualitatif, sebuah penelitian yang berusaha mengungkap keadaan yang bersifat alamiah secara menyeluruh. Penelitian Kualitatif ini digunakan untuk memahami masyarakat, masalah maupun gejalanya dengan mengumpulnya sebanyak mungkin fakta yang dapat

\footnotetext{
${ }^{15}$ Ibid, kartono K. 2011, hlm 9

16 Pusat bahasa departemen pendidikan nasional, Kamus Bahasa Indonesia, Tim Penyusun Kamus Pusat Bahasa. Jakarta: Pusat Bahasa, 2008, hlm 800
} 
diamati. Sedangkan data yang disajikan dalam bentuk kata-kata dan bahasa. ${ }^{17}$ Penggunaan pendekatan kualitatif dalam penelitian ini untuk menghasilkan kata-kata yang ' tertulis atau lisan dari pelaku atau fakta sesuai hasil penelitian penulis.

Metode yang digunakan adalah metode deskriptif yang bertujuan untuk menggambarkan masalah secara sistematis serta menggambarkan fenomena fenomena yang ada secara alamiah maupun rekayasa manusia. Metode deskriptif dipilih karena beberapa pertimbangan yaitu Pertama menggambarkan apa adanya sesuai dengan kenyataan yang ada; Kedua metode ini mempunyai makna yang luas bisa mencakup kuantitatif dan kualitatif; Ketiga metode ini merupakan metode yang paling dasar dari penelitian non eksperimental. ${ }^{18}$ Metode deskriptif ini digunakan untuk mendapatkan data yang akurat.

\section{B. Subjek dan Lokasi Penelitian}

Subjek penelitian ini adalah anak mucikari yang bertempat tinggal di lokalisasi Gambilangu Mangkang Semarang. Mereka ini dalam penelitian kualitatif dijadikan sebagai responden utama, sedangkan responden pelengkap diambil dari orang tua (mucikari), pengurus masjid, pengurus Lokalisasi Gambilangu Mangkang Semarang, tokoh agama dan masyarakat.

Alasan pemilihan lokasi penelitian ini di lingkungan lokalisasi mangkang terdapat masjid, hal ini menunjukkan bahwa di lingkungan tersebut terdapat tanda-tanda kehidupan beragama dan desa tersebut merupakan lokalisasi terbesar kedua di semarang stelah lokalisasi sunan gambilangu mangkang semarang.

\section{Sumber Data}

Data penelitian ini terdiri dari data pokok (primer) dan data penunjang (sekunder). Data primer yang digali dalam penelitian ini terdiri dari

\footnotetext{
${ }^{17}$ Moleong, Lexy J, 2013, Metode Penelitian Kualitatif, Bandung, Remaja Rosda Karya, hlm 6

${ }^{18}$ Sukmadinata, Nana Syaodih, 2013, Metode Penelitian Pendidikan, Bandung, Remaja Rosda Karya, hlm 74
} 
permasalahan pokok yang diteliti, yaitu:

1. Pelaksanaan pendidikan agama pada anak mucikari.

2. Aspek-aspek pengetahuan yang di dapat kan anak mucikari dalam pelaksanaan Pendidikan Agama Islam

3. Motifasi anak mucikari dalam mengikuti kegiatan keagamaan di kalangan

\section{Teknik Pengumpulan Data}

Data lapangan dalam penelitian ini, dikumpulkan melalui teknik- teknik berikut:

1. Observasi

Observasi (pengamatan) digunakan untuk menggali data yang berkaitan dengan lingkungan tempat berdomisili para anak mucikari, sarana tempat beribadah, tempat-tempat hiburan, interaksi para sesama anak mucikari, mucikari dan Pekeija Seks Komersial (PSK).

2. Wawancara

Penulis melakukan wawancara baik secara terikat maupun bebas. Penulis menggunakan metode wawancara terikat agar untuk mengungkap fakta fenomena sosial-pendidikan para anak mucikari yang disusun oleh penulis secara terinci. Penulis juga menggunakan wawancara bebas, namun apabila dalam melaksanakan wawancara terikat tidak mengungkapkan data lebih akurat. Maka metode wawancara bebas sebagai metode mendapatkan data lebih akurat dari objek kajian penelitian tersebut.

Wawancara digunakan untuk menggali data yang berhubungan dengan pelaksanaan pendidikan agama pada anak mucikari, aspekaspek pengetahuan yang di dapatkan anak mucikari dalam pelaksanaan Pendidikan Agama Islam, motifasi anak mucikari dalam mengikuti kegiatan keagamaan di kalangan lokalisasi gambilangu mangkang dan sikap keberagamaan anak mucikari di kalangan lokalisasi gambilangu mangkang.

\section{Studi Dokumentasi}

Teknik ini dilakukan dengan menggali data melalui dokumen yang 
berkaitan dengan gambaran umum lokasi, yaitu sejarah berdirinya Lokalisasi mangkang atau GBL, tujuan didirikannya Lokalisasi tersebut, jenis kelamin anak mucikari, umur. Teknik ini sifatnya melengkapi data dan informasi yang telah diperoleh melalui observasi dan wawancara.

\section{HASIL PENELITIAN}

1) Pendidikan Agama Pada Anak Mucikari di Lokalisasi Gambilangu Mangkang Semarang

Pendidikan Agarna pada anak mucikari diperoleh dari 3 (tiga) lembaga pendidikan yaitu secara formal, Taman Pendidikan A1-Qur'an (TPQ) dan masjid.

a. Pendidikan secara formal

Pendidikan formal ini mereka peroleh dari bangku Taman Kanak-kanak dan Sekolah Dasar. Para anak mucikari banyak mendapatkan Pendidikan Agama Islam di musolla . Adapun lingkup dari Pendidikan Agama Islam di Sekolah formal ini meliputi Al-Qur'an Hadits, Aqidah dan Akhlak dan Tarikh ( Depdiknas, 2007: 2).

b. Taman Pendidikan Al-Qur'an ( TPQ )

Lembaga Pendidikan Agama Islam berikutnya adalah Taman Pendidikan Al-Qur'an (TPQ). Taman Pendidikan Al-Qur'an adalah lembaga pendidikan Islam tingkat dasar di luar sekolah. Pesertanya secara umum memang ditujukan pada anak-anak usia taman kanal- kanak (TK), tetapi praktiknya sering ditemui anak-anak usia SD atau SLTP bahkan yang ingin lancar membaca Al Qur'an. Taman Pendidikan Al-Qur'an ini merupakan salah satu pendidikan non formal yang ada di lokalisasi gambilangu mangkang semarang, Semarang Para anak mucikari juga mendapatkan Pendidikan Agama Islam di TPQ di desa tetangga, Sumberrejo Kecamatan Kaliwungu Kabupaten Kendal. Materi pendidikan agama di TPQ meliputi materi pokok dan materi penunjang. Adapun materi pokok (iqra', gharib/muskilat, al-Qur'an dan tajwid, khot, bahasa arab, fiqih, aqidah akhlak, sejarah Islam) dan materi 
penunjang (hafalan do'a, hafalan juz 'arnma, hafalan bacaan shalat, praktek ibadah), yang didiktatkan oleh TPQ bagi pelaksanaan pendidikan keagamaan anak sudah mencakup dan memenuhi materi Pendidikan Agama Islam. ${ }^{19}$

\section{2) Aspek- aspek Pendidikan Agama Islam yang diperoleh oleh anak Mucikari}

Tiga aspek Pendidikan Agama Islam diajarkan kepada anak mucikari meliputi:

a. Pendidikan akidah/keimanan; untuk menghasilkan generasi muda masa depan yang tangguh dalam iman dan taqwa dan terhindar dari aliran atau perbuatan yang menyesatkan para anak mucikari dan pergaulan bebas yang akhjr-akhir ini sangat méngkhawatirkan.

b. Pendidikan ibadah; diajarkan kepada anak-anak untuk membangun generasi muda yang punya komitmen dan terbiasa melaksanakan ibadah, seperti shalat, puasa, membaca Al-Quran. Peran orang tua dan tokoh agama sangat diperlukan dalam memberikan contoh dan teladan yang baik bagi anak-anak.

c. Pendidikan akhlakul-karimah; untuk melahirkan generasi rabbani, atau generasi yang bertaqwa, cerdas dan berakhlak mulia. ${ }^{20}$

\section{3) Kegiatan Keagamaan Anak Mucikari}

Pendidikan Agama Islam tidak hanya dilakukan di madrasah, tetapi juga di lingkungan masyarakat, yang dilaksanakan di masjid-masjid yang ada di sekitar kelurahan mangkang gambilangu. Pendidikan agama bagi anak mucikari juga mereka dapatkan dari masjid, yakni masjid Baiturrahmah Kalibanteng Kulon Semarang Barat.

Adapun bentuk-bentuk pendidikan agama yang diberikan kepada mereka antara lain:

\footnotetext{
${ }^{19}$ Hasil Wawancara dengan ibu Sukinah Selaku Ketua RT 03/RW VI Mangkang Kulon, Kecamatan Tugu, kota Semarang, 02/12/2016

20 Wawancara dengan Pembina Agama Bapak Rusmani Gambilangu Mangkang Semarang, Semarang, 20 November 2016
} 
a. Shalat Maghrib Berjamaah

Shalat maghrib berjamaah yang diadakan di masjid yang ada di lingkungan lokalisasi Gambilangu Mangkang Semarang. Setelah selesai melaksanakan shalat berjamaah maghrib biasanya diikuti dengan wiridan bersama. Tujuan dari pelaksanaan kegiatan shalat jamaah maghrib, diantaranya melatih anak-anak untuk tepat waktu dalam melaksanakan sholat fardhu, melatih anak-anak untuk gemar melaksanakan shalat berjamaah dan melatih menjadi pemimpin atau imam dalam menunaikan shalat berjamaah yang sewaktu- waktu jika ia telah pantas untuk terjun ke masyarakat tidak canggung bila ditunjuk untuk menjadi imam shalat. Namun dari segi aktifitas anak-anak dalam melaksanakan shalat berjamaah masih labil, artinya terkadang mereka aktif dalam mengikuti kegiatan ini, terkadang tidak aktif.

b. Jamaah Yasinan

Suatu kegiatan membaca ayat A1-Quran yang berupa Surat Yasin, dibaca oleh setiap anak-anak secara bersama-sama. Waktu pelaksanaannya diatur setiap malam Jumat atau setelah shalat maghrib di masjid yang ada di lokalisasi gambilangu mangkang semarang, Semarang. Dalam pembacaan surat Yasin dilakukan secara bersama yang dipimpin oleh imam masjid. Adapun maksud dari pelaksanaan kegiatan ini adalah disamping untuk memperlancar bacaan Al-Qur'an juga mengharapkan pahala dan sebagai penenang hati bagi anak-anak yang mengalami kegoncangan jiwa.

c. Peringatan Hari Besar Islam ( PHBI )

Musolla Sabilunnajah mangkang Barat secara teratur dan rutin melaksanakan kegiatan peringatan hati hari besar Islam, seperti maulid Nabi, Isra dan Mi'raj, tahun baru Islam dan sebagainya. Pada kesempatan itu semua anak, para orangm tua diundang, begitu juga para tokoh masyarakat, maka ketika itu ketua 
takmir dan panjtia dalam sambutannya juga menekankan pentingnya Pendidikan Agama Islam.

d. Santunan Bencana Alam

Suatu bentuk kegiatan anak-anak di lingkungan lokalisasi Gambilangu Mangkang Semarang berupa pemberian santunan kepada salah satu keluarga atau beberapa keluarga di suatu daerah tertentu yang sedang mengalami musibah. Kegiatan ini dilaksanakan satu tahun sekali tergantung dari situasi suatu keluarga atau beberapa keluarga dalam suatu daerah yang sedang ditimpa musibah. Maksud dari pelaksanaan kegiatan ini untuk anak-anak adalah mendidik rasa solidaritas yang tinggi terhadap sesama untuk gemar memberikan sumbangan dari kelebihan harta yang mereka miliki kelak setelah dewasa.

e. Kerja Bakti di Masjid dan Lingkungan Lokalisasi Gambilangu Mangkang Semarang

Kegiatan ini merupakan program praktek dari pengamalan sila pertama yaitu Ketuhanan Yang Maha Esa. Adapun pelaksanaan kegiatan ini dikoordinir oleh pengurus masjid yang diadakan pada hari Minggu. Lokasi kerja bakti yakni di masjid dan musholla-musholla yang ada di lingkungan lokalisasi Gambilangu Mangkang Semarang. Adapun tujuan dari program ini adalah mendidik kesadaran anak- anak untuk memperhatikan dan memelihara tempat-tempat ibadah dan menjadi solidaritas antar anak-anak dengan masyarakat di lingkungannya.

Secara khusus lembaga pendidikan keagamaan belum begitu banyak yang disediakan untuk anak mucikari sekitar dalam memperoleh Pendidikan Agama Islam. Dari beberapa aktifitas keagamaan yang dilakukan oleh para anak mucikari Gambilangu Mangkang Semarang 
seperti yang telah penulis sebutkan di atas menunjukkan kehidupan mereka yang agamis, meskipun masih minim. ${ }^{21}$

\section{4) Implementasi Pendidikan Agama di Lokalisasi Gambilangu Mangkang} Semarang

Peran orang tua dalam mendidik anak sangat menentukan dalam pembentukan karakter dan perkembangan kepribadian pada anak. Disadari maupun tidak disadari, anak-anak dapat terkena imbas dari globalisasi yang negatif, terutama bila dalam tumbuh kembangnya tidak diimbangi dengan 0 perhatian dan bimbingan dari orang tua. Terlebih lagi bila anak-anak bertempat tinggal di lingkungan yang tidak baik serta tidak mendapat pendidikan agama yang baik. Pelayanan Pendidikan Agama Islam secara khusus tidak ada, Pendidikan Agama pada masyarakat untuk orang dewasa adalah Pendidikan agama berupa pengajian majlim taklim, kegiatan PHBI, kegiatan keagamaan meliputi mulai dari kelahiran, khitan, pernikahan, tujuh bulanan, kematian (3 hari, 40 hari, 100 hari dst). Sedangkan pendidikan agama untuk anak-anak adalah TPQ (Taman Pendidikan A1-Qur'an).

Penyelenggaraan majlis taklirn ini pada setiap malam rabu bagi kaum bapak-bapak dan dilaksanakan setelah shalat isya' sampai jam 21.30 wib. Sedangkan kaum ibu-ibu dilaksanakan pada malam jumat yang dimulai setelah sholat isya' sampai jam 21.30 wib. Kegiatan majlis taklim bagi kaum remaja dilaksanakan pada malam jumat yang dimulai setelah sholat isya' sampai jam 21.30 wib, begitupun juga kegiatan TPQ untuk anak-anak diselenggarakan di masjid tetangga desa dan musholla yang ada disekitar lingkungan lokalisasi Gambilangu Mangkang Semarang yang dimulai pukul 15.30 sampai pukul 17.00 wib, ada pula yang setelah magrib. Kegiatan TPQ untuk anak-anak terpaksa diselenggarakan di sekitar lingkungan lokalisasi, hal ini dikarenakan di lokalisasi Gambilangu Mangkang Semarang itu sendiri

\footnotetext{
${ }^{21}$ Informasi dari Mas Agus Pemuda RT 03 RW 06 Mangkang kulon Kecamatan Tugu Kota Semarang ( Asli Penduduk) 08 Desember 2016
} 
belum didirikan gedung TPQ dan masjid, hanya ada satu Musolla saja dan belum ada Masjid. ${ }^{22}$

\section{SIMPULAN DAN REKOMENDASI}

\section{A. Kesimpulan}

Pendidikan Agama Islam pada anak mucikari di lokalisasi gambilangu mangkang semarang telah berjalan meskipun belum ideal. Anak-anak mucikari memperoleh Pendidikan Agama Islam di sekolah (Sekolah Dasar dan Taman Kanak- Kanak), Taman Pendidikan Al-Qur'an dan masjid. Dari lembaga-lembaga pendidikan tersebut para anak mucikari memperoleh pengetahuan mengenai aqidah/keimanan, ibadah dan akhlak. Motifasi aktifitas keagamaan anak mucikari dalam melaksanakan sholat maghrib berjamaah, méngikuti jama'ah yasin, kegiatan santunan musibah belumlah maksimal. Karena minimnya sarana ibadah dan anak-anak mendapatkan pendidikan agama di Taman Pendidikan Al-Qur'an dan Masjid tetangga Desa dan sebagian ada di Musolla (satu satunya musolla dilokalisasi itu). Hal ini tampak pada motivasi mereka dalam mengikuti aktivitas spiritual yang diadakan di lingkungan lokalisasi hanya sampai batas pengetahuan ajaran agama, belum sampai pada tingkat pengamalan.

\section{B. Rekomendasi}

1) Perlu adanya upaya yang dilakukan oleh Kementrian Agama untuk menugaskan para da'i/ relawan untuk memberikan pelayanan Pendidikan Agama Islam kepada para anak mucikari dan orang tuanya serta penduduk di lingkungan lokalisasi Gambilangu Mangkang Semarang

2) Kepada pengelola lokalisasi Gambilangu Mangkang Semarang agar meningkatkan sarana dan prasarana ibadah atau hal-hal yang berbau agama, sayang di sayangkan ketika hanya ada satu musolla ditemept

${ }^{22}$ masih minimnya sarana ibadah salah satunya disebabkan karena penduduk lokalisasi tersebut sebagian pendatang, dengan tujuan bisnis karaoke dan menyediakan tempat esek-esek, sehingga kesadaran beragama dan mengarahkan pendidikan agama pada anak-anak masih belum maksimal (wawancara Ibu Kanisih selaku resos "kordinator mucikari" di lokalisasi Mangkang Barat RT 03 RW 06 Kecamatan Tugu kota Semarang, 15 Desember 2016). 
tersebut, sehingga dapat meningkatkan kesadaran beragama dan meningkatkan iman dan taqwa bagi masyarakat lokalisasi sendiri sehingga kemaksiatan berkurang, dan akhirnya diharapkan bisa sima.

3) Kepada para orang tua yang berprofesi sebagai mucikari untuk lebih meningkatkan kesadaran bermasyarakat dan kesadaran rnenjalankan ajaran agama agar menj adi orang tua yang sepenuhnya menjadi teladan yang baik bagi anak-anaknya serta meninggalkan atau beralih profesi yang lebih baik dan halal.

4) Kepada anak-anak di lokalisasi Gambilangu Mangkang Semarang hendaklah lebih mendalami ilmu agama, memahami dan menjalankan perintah agama sehingga dapat terhindar dari segala yang buruk dan dilarang oleh agama.

\section{DAFTAR PUSTAKA}

A.L. Tibawi , 1972, Islamic Education in Traditions and Modernization into the Arab National Systems, London: Luzac Company Ltd.

Abu al-Abbas Syihabuddin Ahmad Al-Qarafi, 1973, Anwar al-Buruq fi Anwa al-Furuq, Alam al -Kutub, tt. vol. II, hal. 33. Lihat juga karyanya yang bertitel alDzakhirah Beirut: Dar al-Gharb al-Islami, cet. I, 1994, vol.I, hal. 153-154, dan Syarh Tanqih al-Fushul, Syirkah al- Thaba' ah al-Fanniyah alMuttahidah, cet. I, 
Abu al-Abbas Syihabuddin Ahmad Al-Qarafi, al-Dzakhirah, vol. I.

Abuddin Nata, Filsafat Pendidikan Islam, 1997, Jakarta: Logos Wacana Ilmu,

Ahmad Tafsir, Lihat pula Asmaran As, Karakteristik Epistemologi Islam (Ke Arah Pemahaman Dunia Sufistik), dalam Jurnal Khazanah, Volume IV, Nomor 03, Mei - Juni 2005.

Ali, Maulana Muhammad, 1990, The Religion of Islam, USA: The Ahmadiyya Anjuman Ishaat Islam Lahore.

Al-Syaibany, 1979, Falsafah al-Tarbiyyah allslamiyyah, Alih Bahasa: Hasan Langgulung, Falsafah Pendidikan Islam (Jakarta: Bulan Bintang.

Arikunto, Suharsimi, 2010, Prosedur Penelitian: Sumber Pendekatan Praktik, Jakarta, Rineka Cipta.

As Hornby, 1974, Oxford Advanced Leaner's Dictionary of Current English, Mexico: Oxford University Press.

Barnawi dan Mohammad Arifin, 2012, Etika dan Profesi Pendidikan, ArRuzz Media, Yogyakarta.

Daradjat, Zakiah, 2005, Ilmu Jiwa Agama, Jakarta: Bulan Bintang.

Dennis Howitt \& Duncan Cramer, 2005, Introduction to Research Methods in Psichology, England: Pearson Prentice Hall.

Departemen Agama Republik Indonesia, 2005. Al-Qur'an dan Terjemahnya, Semarang, PT. Kumudasmoro Grafindo

Depdiknas, 2012, Kamus Besar Bahasa Indonesia, Jakarta: Balai Pustaka.

Djatnika Rahmat, 2012, Sistem Etika Islam (Surabaya: Pustaka Islam 1985).

E. Mulyasa, 2004), Kurikulum Berbasis Kompetensi, Konsep, Karakteristik, dan Implementasi, (Bandung: PT. Remaja Rosdakarya, Cet. Ke-6.

Elizabeth, Zulfa, 2011, Pendidikan Agama Anak Suku Kalang, Jurnal Walisongo, November 2011, 451-463.

Faiqoh, 2012, Pelayanan Pendidikan Keagamaan Pada Komunitas Anak Jalanan di Kota Medan, Jurnal Edukasi, April 2012, 60-75.

Frost, Nollaig, 2011, Qualitative Research Methods in Psychology Combining Core Aprroaches, New York: Mc Graw Hill. 
Fuad Kauma, 1999, Sensasi Remaja di Masa Puber, Jakarta : Kalam Mulia.

Gunawan, Heri, 2014, Pendidikan Islam ( Kajian Teoritis dan Pemikiran Tokoh), Bandung: Remaja Rosda Karya .

Hamdani Ihsan dan Fuad Ihsan, 1998, Filsafat Pendidikan Islam, (Bandung: Pustaka Setia.

Hasbullah. 1999. Dasar-dasar Ilmu Pendidikan. Cet. I. Jakarta: Raja Grafindo Persada

Heriana Eka Dewi, Memahami Perkembangan Fisik Remaja, (Yogyakarta : Gosyen Publishing).

Jalaluddin dan Usman Said. 1999. Filsafat Pendidikan Islam (Jakarta: Rajawali Press.

Jalaluddin, 2013, Teologi Pendidikan, Jakarta: PT Raja Grafindo Persada.

Kartono, K. 2011. Patologi Sosial. Jakarta : PT. Radja Grafindo Persada

Langgulung Hasan, 1995. Manusia dan Pendidikan: Suatu Analisa Psikologi dan Pendidikan. (Cetakan Ketiga). Jakarta: Al-Husna Zikra

Mahmud Syaltout., Lil Alamil Akbar, 1966, Al Islam Aqidah Wa Syari'ah, Mesir: Darul Qolam.

Moleong Lexy J, 2013, Metode Penelitian Kualitatif, Bandung, Remaja Rosda Karya

Muhammad Athiyah Al-Abrasyi, Ruh at-Tarbiyyah wa at-Ta'lim, Isa Babil Halabi Wa Sirkah Kairo

Mujamil Qomar, Epistemologi Pendidikan Islam, Dari Metode Rasional Hingga Metode Kritik, (Jakarta: Erlangga, 2005)

Purwojuono, Ribut, Hamka's Education Thinking: Gender Equality in Islamic Education, Journal of Social Sciences and Humanities, 2015, 105-113.

Rayyan, Shobhi, 2012, Islamic Philosophy of Education, Intemational Journal of Humanities and Social Science, 150-156.

Samsul Nizar dan Al-Rasyidin, 1995. Filsafat Pendidikan Islam (Jakarta, Ciputat Press). 
Tafsir, Ahmad, 2012, Ilmu Pendidikan dalam Perspektif Islam, Bandung: PT Remaja Rosdakarya

Zainal Arifin \& Adhi Setiawan, 2012, Pengembangan Pembelajaran Aktif Skripta, Yogyakarta

Zakiah Daradjat,. 1996. Ilmu Jiwa Agama (Cetakan Kelima belas). Jakarta: Bulan Bintang.

Hasil Wawancara dengan Ibu Sukinah Selaku Ketua RT 03/RW VI Mangkang Kulon, Kecamatan Tugu, kota Semarang, 02/12/2016

Wawancara dengan Pembina Agama Bapak Rusmani Gambilangu Mangkang Semarang, Semarang, 20 November 2016

Wawancara Ibu Anggun pendatang dari jepara (bukan nama sebenarnya) yang bertempat di lokalisasi RT 04 RW 06 (rumah kontrak yang digunakan untuk bisnis karaoke dan esek-esek)15 Desember 2016

wawancara Ibu Kanisih selaku Resos "kordinator mucikari" di lokalisasi Mangkang Barat RT 03 RW 06 Kecamatan Tugu kota Semarang, 15 Desember 2016

Wawancara Informasi dari Mas Agus Pemuda RT 03 RW 06 Mangkang kulon Kecamatan Tugu Kota Semarang ( Asli Penduduk) 08 Desember 2016 